PHARMACON- PROGRAM STUDI FARMASI, FMIPA, UNIVERSITAS SAM RATULANGI,

Volume 9 Nomor 4 November 2020

COMPARATIVE ANALYSIS OF THE SATISFACTION LEVEL OF NATIONAL HEALTH INSURANCE PATIENTS WITH PHARMACEUTICAL SERVICES AT THE LANGOWAN DISTRICT COMMUNITY HEALTH CENTER

\title{
ANALISIS PERBANDINGAN TINGKAT KEPUASAN PASIEN JKN TERHADAP PELAYANAN KEFARMASIAN DI PUSKESMAS KECAMATAN LANGOWAN
}

\author{
Aprilia Massie $^{1)}$, Widya Astuty Lolo ${ }^{1)}$, Imam Jayanto ${ }^{1)}$ \\ 1) Program Studi Farmasi FMIPA UNSRAT Manado, 95115 \\ *priliamassie.am@gmail.com
}

\begin{abstract}
Service quality is closely related to patient satisfaction and is an important indicator for pharmaceutical services. Good quality service will give satisfaction to patients so that it affects patients to return to the Public health center The purpose of this study was to determine the comparison of the satisfaction levels of outpatient JKN participants with pharmaceutical services at the Langowan District Health Center. The results showed that the overall average value of patient satisfaction at the Tumaratas Health Center was (-0.49) while at the Walantakan Health Center it was (-0.62) with the difference between the two health centers of (-0.13), so it can be concluded that Patient satisfaction level is more satisfying at Public health center Tumaratas compared to Public health center Walantakan
\end{abstract}

Keywords : Public health center, National health insurance, satisfaction level

\begin{abstract}
ABSTRAK
Kualitas pelayanan sangat erat kaitannya dengan kepuasan pasien dan merupakan indikator penting bagi pelayanan kefarmasian. Kualitas pelayanan yang baik akan memberikan kepuasan kepada pasien sehingga mempengaruhi pasien untuk kembali lagi ke puskesmas. Tujuan dari penelitian ini untuk mengetahui perbandingan Tingkat Kepuasan pasien peserta JKN rawat jalan terhadap pelayanan kefarmasian di Puskesmas Kecamatan Langowan. Penelitian ini merupakan penelitian deskriptif dan alat pengumpulan data yang digunakan yaitu kuesioner diberikan kepada 265 dan 226 responden. Hasil penelitian diperoleh rata-rata secara keseluruhan nilai kepuasan pasien di Puskesmas Tumaratas didapatkan sebesar $(-0,49)$ sedangkan di Puskesmas Walantakan sebesar $(-0,62)$ dengan selisih antara kedua puskesmas sebesar $(-0,13)$, sehingga dapat disimpulkan bahwa tingkat kepuasan pasien lebih memuaskan pada Puskesmas Tumaratas di bandingkan pada Puskesmas Walantakan.
\end{abstract}

Kata kunci : Puskesmas, JKN, Tingkat Kepuasan 


\section{PENDAHULUAN}

Kesehatan merupakan hal terpenting dalam kehidupan masyarakat, karena dalam keadaan sehat individu mampu melakukan tindakan sosial maupun ekonomi untuk meningkatkan kehidupan (Jamil, L. 2006). Dalam Undang-Undang No. 36 Tahun 2009 tentang Kesehatan bahwa kesehatan adalah keadaan sehat, baik secara fisik, mental, spiritual maupun sosial yang memungkinkan setiap orang untuk hidup produktif secara sosial dan ekonomi. Hal tersebut menekankan bahwa aspek kesehatan menjadi utama untuk tercapainya kesempurnaan hidup. Ironisnya di Indonesia kualitas kesehatan masyarakat masih tergolong rendah. Hal ini berdasarkan hasil survei American International Assurance (AIA) Tahun 2009 Group yang menempatkan indonesia di posisi terendah dari 15 pada kategori sebagai negara kualitas kesehatan terendah negara di wilayah AsiaPasifik (Fajaruddin, 2015).

BPJS Kesehatan sebagai Badan Pelaksana merupakan badan hukum publik yang dibentuk untuk menyelenggarakan program jaminan kesehatan bagi seluruh rakyat Indonesia. Tujuan diberlakukannya program Jaminan Kesehatan Nasional ini adalah untuk memenuhi kebutuhan kesehatan masyarakat yang layak yang diberikan kepada setiap orang yang telah membayar iuran atau iurannya dibayar oleh Pemerintah (BPJS Kesehatan 2014).

Tingkat kesadaran masyarakat tentang kesehatan semakin tinggi yang berbandingan lurus dengan semakin banyaknya masalah kesehatan yang dihadapi, mendorong pemerintah untuk memaksimalkan jangkauan pelayanan kesehatan kepada masyarakat. Salah satu tempat pelayanan kesehatan bagi masyarakat adalah puskesmas. Puskesmas adalah unit pelaksana teknis dinas kesehatan kabupaten atau kota yang bertanggung jawab menyelenggarakan pembangunan kesehatan di suatu wilayah kerja (Permenkes No. 74 tahun 2016).

Saat ini puskesmas juga melaksanakan pelayanan farmasi klinik meliputi pelayanan resep, peracikan obat, penyerahan obat dan pemberian informasi obat kepada masyarakat baik sebagai pasien umum dan peserta asuransi BPJS bidang kesehatan. Pemberian informasi obat juga akan mempengaruhi kepuasan pasien (Ifmaily, 2006).

Pasien sebagai sumber pengendali dalam pelayanan kesehatan harus memperoleh informasi yang dibutuhkan baik itu penyakit maupun obat yang diberikan karena informasi tersebut akan membantu pasien untuk berpartisipasi dalam mengambil keputusan medis dan penentuan keberhasilan pemulihan pasien. Hubungan yang baik di antara petugas kesehatan dan pasien dalam pelayanan kesehatan membentuk persepsi positif pasien dan akan berkontribusi pada peningkatan citra puskesmas di masyarakat (Pohan, 2007).

Hasil penelitian dari analisis perbedaan tingkat kepuasan pasien pelayanan rawat jalan di Puskesmas berstatus akreditasi utama dan paripurna di Kota Semarang dilihat dari lima dimensi service quality pasien merasa puas dari semua dimensi (Nimas, et al., 2018). Sedangkan penelitian Perbandingan Tingkat Kepuasan di puskesma Kecamatan Langowan didapatkan hasil pasien kurang puas dari lima dimensi reliability, assurance, tangibles, responsiveness, dan empaty.

Berdasarkan hasil wawancara yang dilakukan di Puskesmas Kecamatan Langowan, belum pernah dilakukan penelitian terhadap perbandingan tingkat kepuasan pasien terhadap kualitas pelayanan obat di Puskesmas Kecamatan Langowan. Hal ini mendorong peneliti untuk melakukan penelitian tersebut. 


\section{METODOLOGI PENELITIAN}

\section{Waktu dan Tempat Penelitian}

Penelitian ini dilaksanankan di Puskesmas Tumaratas dan Puskesmas Walantakan Kecamatan Langowan, periode bulan Juni - Agustus 2020

\section{Jenis Penelitian}

Penelitian ini merupakan penelitian deskriptif. Pengumpulan data menggunakan kuesioner kepada responden. Kuesioner yang diisi oleh responden dikumpulkan kembali untuk diolah lebih lanjut.

\section{Alat dan Bahan}

Alat

Alat yang digunakan pada penelitian ini adalah alat tulis menulis, lembar kuesioner, dan kamera untuk dokumentasi.

\section{Bahan}

Data yang digunakan terdiri dari dua sumber data yaitu :

1. Data primer diperoleh dari hasil kuesioner yang diisi oleh responden

2. Data sekunder berupa pengumpulan data yang dilakukan melalui studi bahan kepustakaan yang perlu untuk mendukung data primer.

\section{Populasi Penelitian}

Populasi dalam penelitian ini merupakan wilayah yang ingin diteliti oleh peneliti, populasi adalah suatu objek yang mempunyai karakteristik tertentu yang ditetapkan oleh peneliti untuk dipelajari dan kemudian ditarik kesimpulannya. Populasi dalam penelitian ini yaitu pasien atau pengunjung di Puskesmas Tumaratas dan Puskesmas Walantakan Kecamatan Langowan.

\section{Sampel Penelitian}

Sampel yang digunakan dalam penelitian ini adalah pasien peserta Jaminan Kesehatan Nasional di Puskesmas
Tumaratas dan Puskesmas Walantakan Kecamatan Langowan yang memenuhi kriteria inklusi dan eksklusi :

1. Kriteria Inklusi :

a. Pasien Dewasa $\geq 17$ tahun (Depkes, 2009).

b. Peserta Jaminan Kesehatan Nasional

c. Bersedia menjadi responden

2. Kriteria Eksklusi :

a. Pasien yang baru pertama kali mendapatkan pelayanan kefarmasian di puskesmas

b. Pasien cacat / buta huruf

Rumus yang digunakan untuk menghitung besaran sampel adalah rumus Slovin ( Sugiyono, 2013) :

$$
n=\frac{N}{1+N(e)^{2}}
$$

Keterangan:

$\mathrm{n}=$ Besar sampel

$\mathrm{N}=$ Jumlah Populasi

$\mathrm{e}=$ Presentasi kelonggaran ketelitian $(0,05)$.

Dalam penelitian ini, jumlah sampel yang digunakan di Puskesmas Tumaratas sebanyak 265 orang dan Puskesmas Walantakan sebanyak 226 responden/pasien peserta Jaminan Kesehatan Nasional di Puskesmas Kecamatan Langowan.

\section{Analisis Data}

Pengumpulan data menggunakan kuesioner berdasarkan lima dimensi kualitas layanan yaitu Tangible, Reability, Responsiveness, Assurance, Empathy. Semua jawaban diolah dengan penentuan skor berdasarkan skala Likert. Dengan tingkat penilaian sebagai berikut :

1. Tidak puas diberi skor 1

2. Kurang puas diberi skor 2

3. Puas diberi skor 3

4. Sangat puas diberi skor 4 
Dalam menganalisis data dalam penelitian ini menggunakan rumus sebagai berikut:

$$
x=\frac{\sum x i}{n} \quad y=\frac{\sum y i}{n}
$$

Keterangan :

$\mathrm{x}=$ skor rata-rata kenyataan/kinerja

$\mathrm{y} \quad=$ skor rata-rata harapan

$\sum x i=$ Jumlah skor item pernyataan kenyataan

$\sum y i=$ Jumlah skor item pernyataan harapan

Analisis yang digunakan untuk menghitung total kualitas pada penelitian ini menggunakan model Weighted Servqual sebagai berikut (Priyatno, 2010) :

$$
I k j=\sum_{I=0}^{n}(P i j-E i j)
$$

Keterangan :

I $k j=$ Indeks total kualitas pelayanan

Pij = Performance I pada objek $\mathbf{J}$

Eij = Expectance (harapan atribut pada objek j)

$n \quad=$ Jumlah pernyataan.

\section{Uji Validitas dan Reliabilitas \\ Uji Validitas}

Validitas adalah ukuran yang menunjukkan tingkat kesahihan suatu instrumen. Alat ukur yang valid jika benarbenar sesuai dan menjawab tentang variabel yang akan diukur secara cermat. Penghitungan uji validitas ini menggunakan bantuan Statistical Package for the Social Science (SPSS) dan Microsoft Office Excel (Arikunto, 2006).

\section{Uji Reliabilitas}

Reliabilitas adalah instrumen yang digunakan untuk mengukur objek yang sama, akan menghasilkan data yang sama.
Hasil pengukuran yang memiliki tingkat reliabilitas tinggi akan mampu memberikan hasil yang terpercaya. Tinggi rendahnya reliabilitas instrumen ditunjukan oleh angka yang disebut koefisien reliabilitas (Arikunto, 2006).

\section{HASIL DAN PEMBAHASAN}

\section{Karakteristik Responden}

Tabel 3. Karakteristik Pasien BPJS di

$$
\text { Puskesmas Tumaratas Kecamatan }
$$

\begin{tabular}{|c|c|c|}
\hline \multirow[t]{2}{*}{ Karakteristik } & \multicolumn{2}{|c|}{ Total } \\
\hline & $\mathbf{N}$ & $(\%)$ \\
\hline \multicolumn{3}{|l|}{ Jenis Kelamin } \\
\hline Perempuan & 170 & 64 \\
\hline Laki - laki & 95 & 36 \\
\hline \multicolumn{3}{|l|}{ Usia } \\
\hline (17 - 25 Tahun) & 17 & 6 \\
\hline (26 - 35 Tahun) & 40 & 15 \\
\hline (36 - 45 Tahun) & 35 & 12 \\
\hline (46 - 55 Tahun) & 73 & 27 \\
\hline (56 - 65 Tahun) & 85 & 32 \\
\hline (>65 Tahun) & 43 & 16 \\
\hline \multicolumn{3}{|l|}{ Pendidikan Terakhir } \\
\hline SD & 56 & 21 \\
\hline SMP & 54 & 20 \\
\hline SMA & 102 & 38 \\
\hline Diploma/Sarjana & 36 & 13 \\
\hline Lainnya & 17 & 0,6 \\
\hline \multicolumn{3}{|l|}{ Jenis Pekerjaan } \\
\hline Tidak Bekerja / IRT & 125 & 47 \\
\hline Wiraswasta & 25 & 0,9 \\
\hline Buruh / Karyawan & 17 & 0,6 \\
\hline Petani & 40 & 15 \\
\hline Pengajar & 15 & 0,5 \\
\hline PNS & 18 & 0,7 \\
\hline Lainnya & 25 & 0,9 \\
\hline
\end{tabular}

Langowan pada Bulan Agustus Tahun 2020

Keterangan : $\mathrm{n}=$ Jumlah responden/pasien; $\%=$ Persentase 
Tabel 4. Karakteristik Pasien BPJS di Puskesmas Tumaratas Kecamatan Langowan pada Bulan Agustus Tahun 2020

\begin{tabular}{|c|c|c|}
\hline \multirow[t]{2}{*}{ Karakteristik } & \multicolumn{2}{|c|}{ Total } \\
\hline & $\mathbf{N}$ & $(\%)$ \\
\hline \multicolumn{3}{|l|}{ Jenis Kelamin } \\
\hline Perempuan & 135 & 59 \\
\hline Laki - laki & 91 & 40 \\
\hline \multicolumn{3}{|l|}{ Usia } \\
\hline (17 - 25 Tahun) & 19 & 0,8 \\
\hline (26 - 35 Tahun) & 30 & 13 \\
\hline (36-45 Tahun) & 35 & 15 \\
\hline (46-55 Tahun) & 85 & 37 \\
\hline (56-65 Tahun) & 30 & 13 \\
\hline (>65 Tahun) & 27 & 11 \\
\hline \multicolumn{3}{|l|}{ Pendidikan Terakhir } \\
\hline $\mathrm{SD}$ & 20 & 0,9 \\
\hline SMP & 35 & 15 \\
\hline SMA & 110 & 48 \\
\hline Diploma/Sarjana & 54 & 24 \\
\hline Lainnya & 7 & 0,3 \\
\hline \multicolumn{3}{|l|}{ Jenis Pekerjaan } \\
\hline Tidak Bekerja / IRT & 90 & 40 \\
\hline Wiraswasta & 25 & 11 \\
\hline Buruh / Karyawan & 20 & 0,9 \\
\hline Petani & 35 & 15 \\
\hline Pengajar & 15 & 0,6 \\
\hline PNS & 29 & 13 \\
\hline Lainnya & 15 & 0,6 \\
\hline
\end{tabular}

Keterangan : $\mathrm{n}=$ Jumlah responden/pasien; $\%=$

Persentase

Berdasarkan Tabel karakteristik

\section{Jenis Kelamin}

Hasil penelitian menunjukan responden pasien peserta JKN di Puskesmas Tumaratas terbanyak berjenis kelamin perempuan yaitu 170 pasien (64\%), sedangkan hasil penelitian untuk di Puskesmas Walantakan jumlah responden terbanyak 135 pasien (59\%) berjenis kelamin perempuan. Survei nasional di Amerika Serikat menunjukan bahwa wanita memiliki peran yang penting sebagai penentu keputusan dalam pelayanan kesehatan, karena sifat perempuan yang lebih teliti dan peduli dibandingkan laki laki (Kolter et al., 2008). Sedangkan
Menurut Notoatmodjo (2010), penggunaan pelayanan kesehatan oleh perempuan lebih tinggi dibandingkan dengan laki-laki, ini dikarenakan perempuan mempunyai resiko penyakit yang lebih besar dibandingkan dengan laki-laki.

\section{Usia}

Pada penelitian ini, karakteristik responden berdasarkan usia di Puskesmas Tumaratas usia terbanyak yaitu pada rentang 56- 65 tahun sebanyak 85 pasien (32\%), sedangkan di Puskesmas Walantakan usia terbanyak 85 pasien berusia $46-55$ tahun (37\%) merupakan kelompok usia terbanyak. Data tersebut menunjukkan bahwa sebagian besar peserta BPJS kesehatan yang menggunakan layanan kesehatan adalah usia dewasa dan lanjut usia. Semakin tua umur responden kecendurungan untuk lebih sering memanfaatkan pelayanan kesehatan akan lebih tinggi (Sumaryanti, 2000). Pada masa lansia ( $\geq 50$ tahun ) tingkat kepuasan pasien kembali menurun di karenakan faktor usia (Hayaza, 2013).

\section{Pendidikan}

Karakteristik pasien berdasarkan tingkat pendidikan pada kedua puskesmas diketahui bahwa jumlah terbanyak yaitu pada tingkat SMA dengan persentase secara berturut-turut pada Puskesmas Tumaratas dan Puskesmas Walantakan yaitu 120 pasien (38\%) dan 110 pasien $(48 \%)$. Tingkat pendidikan seseorang mempengaruhi tingkat pengetahuannya mengenai kesehatan dibandingkan dengan pasien yang tingkat pendidikan yang rendah. Pendidikan yang semakin tinggi juga memiliki pengetahuan yang baik dan menuntut layanan yang lebih profesional dan kompeten (Sulistyawati, 2011).

\section{Pekerjaan}

Karakteristik berdasarkan pekerjaan pada kedua puskesmas diketahui bahwa 
jumlah terbanyak adalah tidak bekerja/IRT dengan presentase secara berturut-turut pada Puskesmas Tumaratas dan Puskesmas Walantakan yaitu 125 pasien $(47 \%)$ dan 90 pasien (40\%). Robiyanto et al., (2018) dibandingkan dengan mereka yang bekerja, sehingga tidak ada hubungan yang signifikan dengan tingkat kepuasan.

\section{Uji Validitas Kuesioner}

Uji validitas untuk kuesioner diberikan pada 30 responden pada awal penelitian. Berdasarkan hasil analisis yang diperoleh, diketahui bahwa item 1 sampai 24 pada kuesioner harapan dan kenyataan
Sesorang yang tidak bekerja atau ibu rumah tangga mempunyai waktu luang mengurusi semua keperluan rumah tangga termasuk dalam hal menebus obat untuk dirinya sendiri maupun suami atau keluarganya dinyatakan valid karena nilai $r$ hitung lebih besar dari $r$ tabel.

\section{Uji Reliabilitas Kuesioner}

Dari perhitungan menggunakan software SPSS didapatkan bahwa semua item pada kuesioner harapan dan kenyataan dinyatakan reliable dapat dilihat dari nilai cronbach's alfa pada semua dimensi $(\geq 0,6)$.

\section{Analisis Secara Keseluruhan Tingkat Kepuasan Pasien JKN di Puskesmas Tumaratas dan Puskesmas Walantakan Kecamatan Langowan}

Tabel 5. Perhitungan Keseluruhan Tingkat Kepuasan Pasien JKN di Pusksesmas Tumaratas Kecamatan Langowan

\begin{tabular}{|c|c|c|c|c|c|c|c|c|}
\hline Dimensi & Item & Harapan & Kenyataan & $\begin{array}{l}\text { Rata- } \\
\text { rata } \\
\text { Harapan }\end{array}$ & $\begin{array}{l}\text { Rata-rata } \\
\text { Kenyataan }\end{array}$ & Ikj & $\begin{array}{l}\text { Rata- } \\
\text { rata Per } \\
\text { Dimensi }\end{array}$ & Peringkat \\
\hline \multirow[t]{5}{*}{ Tangibles } & 1 & 945 & 865 & 3,57 & 3,26 & $-0,30$ & $-0,38$ & 2 \\
\hline & 2 & 969 & 863 & 3,66 & 3,26 & $-0,40$ & & \\
\hline & 3 & 971 & 844 & 3,66 & 3,18 & $-0,48$ & & \\
\hline & 4 & 974 & 874 & 3,68 & 3,30 & $-0,38$ & & \\
\hline & 5 & 972 & 883 & 3,67 & 3,33 & $-0,34$ & & \\
\hline \multirow[t]{5}{*}{ Reliability } & 1 & 1042 & 884 & 3,93 & 3,34 & $-0,60$ & $-0,69$ & 5 \\
\hline & 2 & 1050 & 878 & 3,96 & 3,31 & $-0,65$ & & \\
\hline & 3 & 1043 & 880 & 3,94 & 3,32 & $-0,62$ & & \\
\hline & 4 & 1048 & 868 & 3,95 & 3,28 & $-0,68$ & & \\
\hline & 5 & 1037 & 795 & 3,91 & 3,00 & $-0,91$ & & \\
\hline \multirow[t]{5}{*}{ Responsiveness } & 1 & 992 & 862 & 4,39 & 3,81 & $-0,58$ & $-0,42$ & 3 \\
\hline & 2 & 972 & 860 & 4,30 & 3,81 & $-0,50$ & & \\
\hline & 3 & 1014 & 910 & 4,49 & 4,03 & $-0,46$ & & \\
\hline & 4 & 1039 & 926 & 4,60 & 4,10 & $-0,50$ & & \\
\hline & 5 & 1040 & 937 & 4,60 & 4,15 & $-0,46$ & & \\
\hline \multirow[t]{2}{*}{ Assurance } & 1 & 1049 & 890 & 4,64 & 3,94 & $-0,70$ & $-0,64$ & 4 \\
\hline & 2 & 1052 & 864 & 4,65 & 3,82 & $-0,83$ & & \\
\hline
\end{tabular}


PHARMACON- PROGRAM STUDI FARMASI, FMIPA, UNIVERSITAS SAM RATULANGI, Volume 9 Nomor 4 November 2020

\begin{tabular}{lcccccccc} 
& 3 & 1051 & 893 & 4,65 & 3,95 & $-0,70$ & & \\
\hline \multirow{2}{*}{ Empaty } & 1 & 1043 & 1007 & 3,94 & 3,80 & $-0,14$ & $-0,30$ & 1 \\
& 2 & 1074 & 972 & 4,05 & 3,67 & $-0,38$ & & \\
& 3 & 1042 & 977 & 3,93 & 3,69 & $-0,25$ & & \\
& 4 & 1044 & 929 & 3,94 & 3,51 & $-0,43$ & & \\
\hline
\end{tabular}

Nilai Kepuasaan Secara Keseluruhan

$-0,49$

Secara keseluruhan tingkat kepuasan pasien di Puskesmas Tumaratas Kecamatan Langowan dapat dilihat Tabel 5. Dari hasil perhitungan tersebut, semua dimensi menggambarkan nilai negatif yang artinya kenyataan yang diterima kurang puas dibandingankan harapan pasien. Dapat dilihat bahwa dimensi empati (empaty) menepati peringkat pertama diantara dimensi lainnya dengan rata - rata nilai Ikj dimensi empati adalah $(-0,35)$ jika hasil ini dianlisis, maka dimensi ini terletak pada rentang negatif yang menunjukan bahwa hasil yang belum memuaskan. Sedangkan dimensi kehandalan (Reliability) menempati peringkat terakhir dengan rata - rata nilai Ikj $(-0,69)$ yang artinya dimensi ini merupakan tingkat kepuasan terburuk.

Tabel 6. Perhitungan Keseluruhan Tingkat Kepuasan Pasien JKN di Pusksesmas Walantakan Kecamatan Langowan

\begin{tabular}{|c|c|c|c|c|c|c|c|c|}
\hline Dimensi & Item & Harapan & Kenyataan & $\begin{array}{l}\text { Rata- } \\
\text { rata } \\
\text { Harapan }\end{array}$ & $\begin{array}{l}\text { Rata-rata } \\
\text { Kenyataan }\end{array}$ & Ikj & $\begin{array}{l}\text { Rata- } \\
\text { rata Per } \\
\text { Dimensi }\end{array}$ & Peringkat \\
\hline \multirow[t]{5}{*}{ Tangibles } & 1 & 828 & 744 & 3,66 & 3,29 & $-0,37$ & $-0,49$ & 2 \\
\hline & 2 & 743 & 729 & 4,46 & 3,23 & $-1,23$ & & \\
\hline & 3 & 822 & 735 & 3,64 & 3,25 & $-0,38$ & & \\
\hline & 4 & 800 & 753 & 3,54 & 3,33 & $-0,21$ & & \\
\hline & 5 & 823 & 762 & 3,64 & 3,37 & $-0,27$ & & \\
\hline \multirow[t]{5}{*}{ Reliability } & 1 & 887 & 711 & 3,35 & 3,15 & $-0,78$ & $-0,69$ & 4 \\
\hline & 2 & 892 & 768 & 3,37 & 3,40 & $-0,55$ & & \\
\hline & 3 & 894 & 758 & 3,37 & 3,35 & $-0,60$ & & \\
\hline & 4 & 890 & 752 & 3,36 & 3,33 & $-0,61$ & & \\
\hline & 5 & 885 & 674 & 3,34 & 2,98 & $-0,93$ & & \\
\hline \multirow[t]{5}{*}{ Responsiveness } & 1 & 829 & 744 & 3,67 & 3,29 & $-0,38$ & $-0,45$ & 1 \\
\hline & 2 & 818 & 731 & 3,62 & 3,23 & $-0,38$ & & \\
\hline & 3 & 852 & 741 & 3,77 & 3,28 & $-0,49$ & & \\
\hline & 4 & 883 & 793 & 3,91 & 3,51 & $-0,40$ & & \\
\hline & 5 & 884 & 750 & 3,91 & 3,32 & $-0,59$ & & \\
\hline \multirow[t]{3}{*}{ Assurance } & 1 & 895 & 714 & 3,96 & 3,16 & $-0,80$ & $-0,81$ & 5 \\
\hline & 2 & 888 & 614 & 3,93 & 2,72 & $-1,21$ & & \\
\hline & 3 & 891 & 795 & 3,94 & 3,52 & $-0,42$ & & \\
\hline
\end{tabular}


PHARMACON- PROGRAM STUDI FARMASI, FMIPA, UNIVERSITAS SAM RATULANGI,

Volume 9 Nomor 4 November 2020

\begin{tabular}{lcccccccc}
\hline Empaty & 1 & 849 & 723 & 3,76 & 3,20 & $-0,56$ & $-0,64$ & 3 \\
& 2 & 887 & 614 & 3,92 & 3,72 & $-1,21$ & & \\
& 3 & 888 & 798 & 3,93 & 3,53 & $-0,40$ & & \\
& 4 & 897 & 778 & 3,85 & 3,44 & $-0,40$ & & \\
Nilai Kepuasaan Secara Keseluruhan & & & & & $\mathbf{- 0 , 6 2}$ & \\
\hline
\end{tabular}

Berdasarkan pada tabel 6 menunjukan bahwa nilai indeks total kualitas pelayanan (Ikj) terendah di tempati oleh dimensi Ketanggapan (Responsiveness) dengan rata - rata nilai Ikj yaitu $(-0,45)$ jika hasil dianalisis, maka dimensi ini berada direntang negatif yang berarti bahwa menunjukan hasil yang belum memuaskan, sedangkan dimensi Ketanggapan (Responsiveness) menepati peringkat terakhir dengan nilai rata - rata nilai Ikj $(-0,81)$ yang artinya dimensi ini merupakan tingkat kepuasan terburuk. Analisis nilai kepuasan keseluruhan berdasarkan rata rata nilai Ikj seluruh item pernyataan di setia dimensi diperoleh nilai sebesar $(-0,62)$.

\section{Gambaran Kepuasan Pasien di Puskesmas Tumaratas dan Walantakan di Kecamatan Langowan Berdasarkan Dimensi Berwujud (Tangible)}

Berdasarkan penelitian di Puskesmas Tumaratas di Kecamatan Langowan yang dapat dilihat dari Tabel 6, nilai indeks total kualitas pelayanan terendah pada angka ($0,91)$ yang terletak pada item 5 dan nilai indeks total pelayanan tertinggi terdapat item 1 dengan angka (-0,60). Secara keseluruhan, pasien belum puas dari dimensi kehandalan (Reliability) karena nilai rata rata (-0,69). Hasil yang diperoleh menunjukan bahwa pada item 5 yang berisi pelayanan informasi obat menggunakan bahasa yang mudah dimengerti pasien, pasien yang berkunjung di Puskesmas Tumaratas merasa tidak puas dengan pelayanan informasi obat menggunakan bahasa yang mudah dimengerti. Sedangkan untuk Puskesmas Walantakan terlihat dari tabel 6, nilai indeks total kualitas pelayanan terendah pada angka $(-0,93)$ yang terletak pada item 5 yaitu pelayanan informasi obat menggunakan bahasa yang mudah dimengerti pasien. Untuk nilai indeks total kualitas pelayanan tertinggi dengan angka ($0,55)$ pada item 2 petugas memberikan keterangan tentang kegunaan obat yang diberikan. Data ini menunjukan bahwa pasien belum puas dilihat dari dimensi kehandalan (Reliability) karena nilai rata rata dimensi yaitu (-0.69). Berdasarkan data, untuk item 5 yaitu pelayanan informasi obat menggunakan bahasa yang mudah dimengerti pasien, hampir sama dengan Pusksesmas Tumaratas bahwa pasien merasa tidak puas terhadap petugas karena petugas menggunakan istilah medis dan kurangnya edukasi sehingga pasien sulit untuk memahami. Menurut Sulistyawati (2011) Adanya sikap membangun komunikasi yang baik dan juga dukungan situasi lingkungan secara fisik di sekitar pasien atau masyarakat merupakan aspek yang berpengaruh terhadap penilaian pasien itu sendiri. Komunikasi dengan pasien tentang suatu proses pelayanan yang sedang diberikan akan menimbulkan suatu persepsi yang positif dan mendukung dirinya untuk dapat menerima pelayanan yang diberikan.

\section{Gambaran Kepuasan Pasien di Puskesmas Tumaratas dan Walantakan di Kecamatan Langowan Berdasarkan Dimensi Kehandalan (Reliability)}

Berdasarkan penelitian di Puskesmas Tumaratas di Kecamatan Langowan yang dapat dilihat dari Tabel 6, nilai indeks total kualitas pelayanan terendah pada angka (- 
$0,91)$ yang terletak pada item 5 dan nilai indeks total pelayanan tertinggi terdapat item 1 dengan angka (-0,60). Secara keseluruhan, pasien belum puas dari dimensi kehandalan (Reliability) karena nilai rata rata $(-0,69)$. Hasil yang diperoleh menunjukan bahwa pada item 5 yang berisi pelayanan informasi obat menggunakan bahasa yang mudah dimengerti pasien, pasien yang berkunjung di Puskesmas Tumaratas merasa tidak puas dengan pelayanan informasi obat menggunakan bahasa yang mudah dimengerti. Sedangkan untuk Puskesmas Walantakan terlihat dari tabel 6, nilai indeks total kualitas pelayanan terendah pada angka $(-0,93)$ yang terletak pada item 5 yaitu pelayanan informasi obat menggunakan bahasa yang mudah dimengerti pasien. Untuk nilai indeks total kualitas pelayanan tertinggi dengan angka (0,55) pada item 2 petugas memberikan keterangan tentang kegunaan obat yang diberikan. Data ini menunjukan bahwa pasien belum puas dilihat dari dimensi kehandalan (Reliability) karena nilai rata rata dimensi yaitu (-0.69). Berdasarkan data, untuk item 5 yaitu pelayanan informasi obat menggunakan bahasa yang mudah dimengerti pasien, hampir sama dengan Pusksesmas Tumaratas bahwa pasien merasa tidak puas terhadap petugas karena petugas menggunakan istilah medis dan kurangnya edukasi sehingga pasien sulit untuk memahami. Menurut Sulistyawati (2011) Adanya sikap membangun komunikasi yang baik dan juga dukungan situasi lingkungan secara fisik di sekitar pasien atau masyarakat merupakan aspek yang berpengaruh terhadap penilaian pasien itu sendiri. Komunikasi dengan pasien tentang suatu proses pelayanan yang sedang diberikan akan menimbulkan suatu persepsi yang positif dan mendukung dirinya untuk dapat menerima pelayanan yang diberikan.
Gambaran Kepuasan Pasien di Puskesmas Tumaratas dan Walantakan di Kecamatan Langowan Berdasarkan Dimensi Ketanggapan (Responsiveness)

Untuk hasil penelitian yang dilakukan di Puskesmas Tumaratas di Kecamatan Langowan yang dilihat dari Tabel 6, nilai indeks total kualitas pelayanan terendah pada angka $(-0,49)$ yang terletak pada item 1 dan nilai indeks total pelayanan tertinggi terdapat item 3 dan 5 dengan angka $(-0,39)$. ). Secara keseluruhan, pasien belum puas dari dimensi ketanggapan (Responsiveness) karena nilai rata - rata dimensi yaitu $(-0,42)$. Hasil yang diperoleh menunjukan bahwa pada item 1 yang berisi pernyataan petugas cepat tanggap menangani keluhan pasien, merasa tidak puas dengan petugas yang kurang cepat tanggap menangani keluhan pasien karena teralu banyak pasien yang datang, sehingga waktu untuk menangani keluhan pasien tidak cukup mengakibatkan petugas kurang tanggap dalam menangani keluhan pasien dikarenakan petugas yang bertugas hanya 1 orang untuk menangani 30 pasien sehingga petugas yang ada di puskesmas tersebut kurang tanggap dalam menangani keluhan pasien. Sedangkan untuk Puskesmas Walantakan terlihat dari tabel 25, nilai indeks total kualitas pelayanan terendah pada angka $(-0,59)$ yang terletak pada item 5 yaitu obat diberikan tepat waktu oleh petugas. Untuk nilai indeks total kualitas pelayanan tertinggi dengan angka $(-0,38)$ pada item 1 dan 2 Petugas cepat tanggap menangani keluhan pasien dan Petugas mampu memberikan solusi terhadap keluhan pasien. Data ini menunjukan bahwa pasien belum puas dilihat dari dimensi kehandalan (Reliability) karena nilai rata - rata dimensi yaitu (-0.45). Berdasarkan data, untuk item 5 yaitu obat diberikan tepat waktu oleh petugas, pasien merasa tidak puas terhadap waktu pemberian obat dengan tepat waktu karena menumpuknya antrian pasien yang 
akan diberikan obat. Berdasarkan ketentuan Permenkes No 129/ Menkes/ SK/ 2008 tentang Standar Pelayanan Minimal Rumah Sakit disebutkan bahwa, untuk obat non racikan $\leq 30$ menit dan obat racikan $\leq 60$ menit. Puskesmas Tumaratas dan Walantakan belum memiliki standar baku waktu tunggu pelayanan resep seperti yang sudah di tetapkan di rumah sakit, namun puskesmas tersebut membuat acuan waktu tunggu berdasarkan ketentuan tersebut yakni waktu tunggu untuk non racikan 5-10 menit sedangkan racikan $10-20$ menit. Menururt Infmaily (2006) ketetapan waktu proses pelayanan dan keterbukaan waktu penyelesaian pelayanan dinilai sangat penting oleh responden.

Gambaran Kepuasan Pasien di Puskesmas Tumaratas dan Walantakan di Kecamatan Langowan Berdasarkan Dimensi Jaminan (Assurance)

Untuk hasil penelitian yang dilakukan di Puskesmas Tumaratas di Kecamatan Langowan yang dilihat dari Tabel 6, nilai indeks total kualitas pelayanan terendah pada angka $(-0,71)$ yang terletak pada item 2 dan nilai indeks total pelayanan tertinggi terdapat item 1 dan 3 dengan angka $(-0,60)$. Secara keseluruhan, pasien belum puas dari dimensi Jaminan (Assurance) karena nilai rata - rata dimensi yaitu $(-0,64)$. Hasil yang diperoleh menunjukan bahwa pada item 2 yang berisi pernyataan petugas memastikan pasien memahami dengan benar informasi tentang obat, pasien yang berkunjung di Puskesmas merasa tidak puas dengan petugas yang kurang memastikan kepada pasien bahwa pasien memahami dengan benar tetang informasi obat. Sedangkan untuk Puskesmas Walantakan terlihat dari tabel 6 , nilai indeks total kualitas pelayanan terendah pada angaka (1,21) yang terletak pada item 2 yaitu pernyataan Petugas memastikan pasien memahami dengan benar informasi tentang obat. Untuk nilai indeks total kualitas pelayanan tertinggi dengan angka $(-0,42)$ pada item 3 yaitu Petugas membungkus obat dengan rapi. Data ini menunjukan bahwa pasien belum puas dilihat dari dimensi Jaminan (Assurance) karena nilai rata - rata dimensi yaitu (-0.45). berdasarkan data, untuk item 2 yaitu pernyataan petugas memastikan pasien memahami dengan benar informasi tentang obat, hampir sama dengan puskesmas Tumaratas. Menurut Permenkes No 74 tahun 2016 tentang Standar Pelayanan Kefarmasian di Puskesmas didalamnya terdapat Pelayanan Informasi Obat (PIO) merupakan kegiatan yang dilakukan oleh apoteker untuk meberikan informasi dan edukasi mengenai obat akan tetapi jumlah Tenaga kesehatan Farmasi di Puskesmas Tumaratas dan Puskesmas Walantakan yaitu hanya 1 tenaga teknis kefarmasian dan petugas yang bertugas bukan hanya tenaga teknis kefarmasian melainkan tenaga medis lain sedangkan jumlah pasien yang datang di puskesmas tiap hari 30 pasien sehingga petugas kurang memastikan kepada pasien tentang informasi obat, karena kurangnya petugas kefarmasian dan semakin banyak permintaan obat di puskesmas maka membuat antrian yang panjang menyebabkan pasien merasa bosan dan jenuh Menurut Nimas 2018 Pemberian berbagai informasi ini sangat penting, menghindari kesalahan penggunaan obat dan efektifitas manfaat obat.

Gambaran Kepuasan Pasien di Puskesmas Tumaratas dan Walantakan di Kecamatan Langowan Berdasarkan Dimensi Empati (Empathy)

Untuk hasil penelitian yang dilakukan di Puskesmas Tumaratas di Kecamatan Langowan yang dilihat dari Tabel 6, nilai indeks total kualitas pelayanan terendah pada angka $(-0,38)$ yang terletak pada item 2 dan nilai indeks total pelayanan tertinggi terdapat item 1 dengan angka (0,14). ). Secara keseluruhan, pasien belum 
puas dari dimensi berwujud (Tangible) karena nilai rata - rata dimensi yaitu $(-0,30)$. Hasil yang diperoleh menunjukan bahwa pada item 2 yang berisi pernyataan petugas bersikap ramah dan sopan, pasien yang berkunjung di Puskesmas merasa tidak puas dengan petugas yang kurang ramah dan tidak sopan terhadap pasien. Sedangkan untuk Puskesmas Walantakan terlihat dari tabel 6 , nilai indeks total kualitas pelayanan terendah pada angaka $(-1,21)$ yang terletak pada item 2 yaitu pernyataan petugas bersikap ramah dan sopan. Untuk nilai indeks total kualitas pelayanan tertinggi dengan angka $(-0,64)$ pada item 3 dan 4 yaitu petugas melakukan komunikasi yang baik dan Petugas memberikan informasi kesehatan tentang obat tanpa pasien harus meminta. Data ini menunjukan bahwa pasien belum puas dilihat dari dimensi kehandalan (Reliability) karena nilai rata rata dimensi yaitu (-0.45). berdasarkan data, untuk item 2 yaitu pernyataan petugas bersikap ramah dan sopan obat, hampir sama dengan puskesmas Tumaratas. Pelayanan yang cepat tanggap didukung sikap yang ramah serta ketulusan dalam menanggapi persoalan yang di hadapi merupakan penunjang dan turut menentukan keberhasilan dalam suatu pelayanan (Hayaza, 2013). Sesuai dengan pendapat bahwa sikap dari seseorang petugas pelayanan kesehatan merupakan salah satu faktor yang menentukan apakah pelayanan yang diberikan bermutu atau tidak, sehingga dengan sikap petugas yang ramah dan sopan dalam memberikan pelayanan dapat menjadi penentu dari kesembuhan seorang pasien, sebaliknya sikap petugas yang kasar dan acuh dapat mengurangi kepusan pasien terhadap pelayanan yang diterimamnya.

\section{KESIMPULAN}

Berdasarkan peneltian yang telah dilakukan, dapat disimpulkan bahwa tingkat kepuasan pasien JKN terhadap pelayanan kefarmasian di Puskesmas Tumaratas lebih tinggi dengan nilai Ikj sebesar $(-0,49)$ dibandingkan dengan Puskesmas Walantakan dengan nilai Ikj sebesar $(-0,62)$.

\section{SARAN}

Perlu dilakukan evaluasi pelayanan kefarmasian di Puskesmas Tumaratas dan Puskesmas Walantakan untuk dapat meningkatkan mutu pelayanan dari setiap dimensi yang masih kurang sehingga dapat memberikan pelayanan kefarmasian yang optimal bagi pasien.

\section{DAFTAR PUSTAKA}

\section{BPJS. 2014. Paduan Praktis Pelayanan Kesehatan. Jakarta.}

Fajaruddin. 2015. Kepuasan Masyarakat Terhadap Pelayanan Kesehatan Pasien Pemegang Kartu Jaminan BPJS di Unit Pelayanan Teknis Kesehatan Puskesmas Kecamatan Bungah Kabupaten Gresik . Universitas Negeri Surabaya. Surabaya.

Hayaza, Y. T 2013. Analisis Kepuasan Pasien Terhadap Kualitas Pelayanan Kamar Obat di Puskesmas Surabaya Utara. Jurnal Ilmiah Mahasiswa Universitas Surabaya. 2 : (2), 2 - 4.

Infmaily. 2006. Analisis Pengaruh Persepsi Layanan Farmasi Pasien Unit Rawat Jalan Terhadap Minat Beli Obat Ulang di Instalasi Farmasi RSI Ibnu Sinayarsi Padang Tahun 2006 [Tesis]. Univesitas Diponegoro. Semarang.

Jamil, L. 2006. Mutu Pelayanan Farmasi di Puskesmas Kota Padang. [Tesis]. Universitas Gadjah Mada, Yogyakarta.

Kolter Hendra, Anntono Suryoputro, Eka Yunita 2008. Analisis Tingkat Kepuasan Pasien Terhadap 
Pelayanan Rawat Jalan di Puskesmas Duren dan Puskesmas Bergas Kabupaten Semarang. Jurnal Kesehatan Masyarakat. 5 : (4).

Nimas, A. D., Sutopo, P J., Eka Y. F. 2018. Analisis Perbedaan Tingkat Kepuasan Pasien Terhadap Mutu Pelayanan Rawat Jalan Puskesmas Berstatus Akreditasi Utama dan Paripurna di Kota Semarang. Jurnal Kesehatan Masyarakat.6 : (5), 128 132.

Peraturan Pemerintah Republik Indonesia. 2016. Peraturan Pemerintah RI Nomor 75 Tahun 2016 tentang Standar Pelayanan Kefarmasian di Puskesmas. Departemenn Kesehatan Republik Indonesia, Jakarta.

Pohan, I. S 2007 Jaminan Mutu Layanan Kesehatan. Kesainct blance, Bekasi.

Sulistyawati, M. 2011 Hubungan Kualitas Pelayanan Farmasi Pasien Rawat Jalan Terhadap Kepuasan dan Keputusan Membeli Ulang Obat di IRRS. Jala Ammari Makassar, Makasar. 